高層建築物の風応答における風直角方向と捩れの固有振動数比の影響 に関する研究

\title{
EFFECTS OF NATURAL FREQUENCY RATIO OF ACROSS-WIND TO TORSION ON WIND-INDUCED RESPONSES OF A HIGH-RISE BUILDING
}

\author{
片 桐 純 治*, 丸川 比佐夫**, 大熊 武司***, 藤 井邦 雄**** \\ Junji KATAGIRI, Hisao MARUKAWA, Takeshi OHKUMA \\ and Kunio FUJII
}

\begin{abstract}
The effects of the natural frequency ratio $n_{\theta} / n_{X}$ of the across-wind to the torsional vibration on wind-induced responses of a high-rise building has been investigated in wind tunnel tests using a multi-degree-of-freedom aeroelastic model with a side-span ratio of 2 and an aspect ratio of 5 . The across-wind response displacement increases steeply as the natural frequency of across-wind vibration close to that of torsional vibration. This phenomenon is caused by the increasing natural frequency component of torsional vibration in the across-wind direction. It is also inherent in motion-induced wind forces in the across-wind direction accompanied by the torsional vibration. However, $n_{\theta} / n_{X}$ has small effects on the aerodynamic damping ratios and the motion-induced wind forces in the across-wind direction. The difference in the wind response in the across-wind direction due to changing $n_{\theta} / n_{X}$ is generated by the difference in the magnification factor in the across-wind direction.
\end{abstract}

\section{Keywords : Natural Frequency Ratio, Multi-Degree-of-Freedom Aeroelastic Model, Aerodynamic Damping, Motion-Induced Wind Force 固有振動数比, 多質点系空力弾性模型, 空力減衰, 振動依存風力}

\section{1.はじめに}

建築物の高層化に伴い, 渦励振, 㧖れフラッターなどの構造物の 振動と周辺の流れとの相互作用によって生じる振動依存風力による 空力不安定振動を考虑した耐風設計が必要となってきている.空力 不安定振動を考虑した耐風設計は,動的天科などで測定された風力 と強制振動実験より求めた振動依存風力を用いて解析的に建築物の 風応答を求める方法1)もしくは振動模型を用いた風洞実験により風

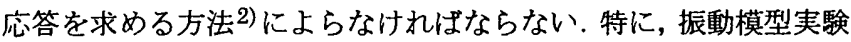
によって㧖れ振動の空力不安定振動を検郡する場合，㨭れの自由度 を有する多質点系空力弾性模型を用いる必要がある.

著者等は，これまで边長比 2, アスペクト比 5 の矩形平面を有す る高層建物の風応答を対象に,多質点系弾性模型を用いた風洞実験 により密度比,減衰定数および偏心の影響に関して検討を行ってき た 3),4).その結果，辺長比 2 の高層建築物では，㨝れ振動の構造减 衰定数が $1 \%$ よ小さい場合あるいは風直角方向振動と挨れ振動の 構造的な連成を有する場合に無次元風速 $U_{H} / n_{0} \sqrt{A}\left(U_{H}\right.$ : 模型頂 部高さの平均風速, $n_{0}$ : 固有振動数, $A$ : 断面積) か 4 付近の比較的 低風速において風外力から推定される応答変位に比較して極めて大 きな応答変位が生じる事を明らかにした。

この中で, 偏心等による構造的な連成を有さない場合にも, 風直
角方向と㧖れの固有振動数が同程度である場合,据れ変位の急激な 増加に伴って風直角方向の応答変位も急激に增加する現象が生じる ことを示しだ). 固有振動数の接近によって風直角方向振動あるい は摸れ振動が増加する現象は, 大熊他 ${ }^{5)}$ の2次元模型を用いた風洞 実験あるいは吉村他6)の3次元模型を用いた風洞実験からも示され ている. また，風直角方向と㨭れの固有振動数に $15 \%$ 程度の差が ある場合にも同様の現象が生じる事が河井7)の実験に示されてい る.これらの現象は, 風外力の測定結果からは予測し得ないもので あり，構造物の振動に伴って生じる振動依存風力によるものと考え られる.しかし，どのようなメカニズムによるものか詳細に検討さ れたものはない.

本研究は, 風直角方向と㨭れの固有振動数比が建築物の風応答 に与える影響に関して, 辺長比 2 , アスペクト比 5 の多質点系弾性 模型による振動実験結果を基に検討を行う. 本研究では, 上記現象 の発生要因について明らかにするとともに,建築物の振動によって 生じる振動依存風力に対する固有振動数比の影響について検討す る.

\section{2. 実験方法概要}

実験は, 測定部高さ $2.0 \mathrm{~m}$, 幅 $3.1 \mathrm{~m}$, 測定部長さ $16 \mathrm{~m} の$ 回流式境
* 陎風工学研究所 主任研究員

***蛛泉創建エンジニアリング構造システム研究室 室長

****神奈川大学建築学科 教授・工博

**** 懒風工学研究所 所長 $\cdot$ 工博
Chief Research Eng., Wind Engineering Institute Co., Ltd. General Manager, R\&D, Izumi Sohken Engineering Co., Ltd. Prof., Dep. of Arch., Kanagawa University, Dr. Eng. President, Wind Engineering Institute Co., Ltd., Dr. Eng. 
界層風洞で行った．実験模型および実験気流は文献3)に用いたも のと同様である. 実験模型は, 図-1に示す辺長比 2, アスペクト比 5 の 6 質点系空力弹性模型である. 実験模型の密度は $200 \mathrm{~kg} / \mathrm{m}^{3}$ と し，高さ方向に一様とした. 実験模型の重心および㓮心は平面中心 と一致している.1次の振動モード形は直線モードに近似している. 風直角方向と㨝れの固有振動数比 $n_{\theta} / n_{X}$ は据れの固有振動数を柱の 位置を変えることによって $1.32 ， 1.11$ および $0.94 の 3$ 種類に変化さ せた．構造減衰定数の調整は，各質点間に粘弾性ゴム (3M VEM ISD111) を張る事によって $0.3 \% 〜 2 \%$ の間で行った. 実験気流は, 郊外風を想定した $\alpha=0.17$ の勾配流である. 乱れ強さおよび乱れの スケールはそれぞれ模型頂部高さで $7 \%$ および $45 \mathrm{~cm}$ である．模型 の応答変位の測定は，渦電流式の非接触変位計を用いて行った. データサンプリング周期は $3.36 \mathrm{~ms}$, データ個数 18000 個とした. 固 有振動数および棈造減衰定数は自由振動実験より求めた.なお, 本 論文の図中に示した構造減衰定数は, 各実験の開始時と終了時に得 られた值の平均値である。

\section{3. 实险緮果}

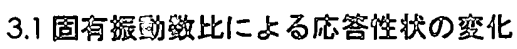

図-2に風直角方向と据れの固有振動数比 $n_{\theta} / n_{X}$ による無次元変位

\begin{tabular}{|c|c|c|}
\hline 厠们 & & \\
\hline 0 & $h s_{x}=0.005$ & $h s_{\theta}=0.003$ \\
\hline 0 & $h s_{x}=0.008$ & $h s_{\theta}=0.005$ \\
\hline$\Delta$ & $h s_{x}=0.015$ & $h s_{\theta}=0.012$ \\
\hline & $h s_{x}=0.017$ & $h s_{\theta}=0.014$ \\
\hline 定定檤 & & \\
\hline & $\varepsilon_{8}=0$. & $h s_{\theta}=0.003$ \\
\hline & $h s_{x}=0.008$ & $h s_{\theta}=0.005$ \\
\hline & $h s_{x}=0.015$ & $\mathrm{hs}_{\theta}=0.012$ \\
\hline & $h s_{x}=0.017$ & $h s_{\theta}=0.014$ \\
\hline
\end{tabular}

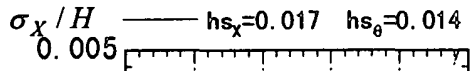

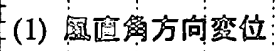

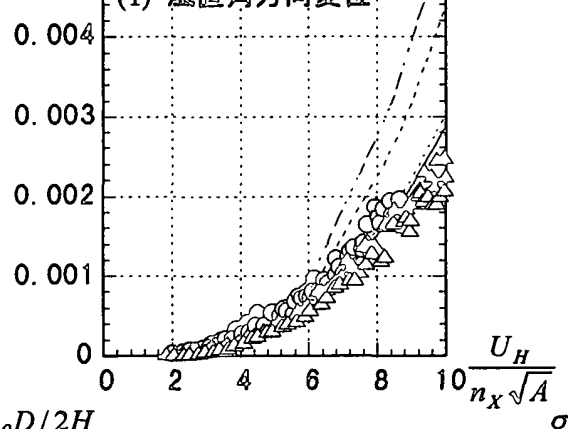

$\sigma_{\theta} D / 2 H$

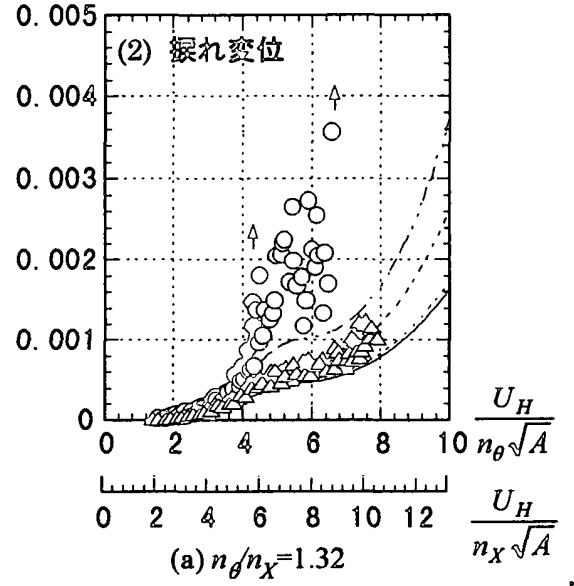

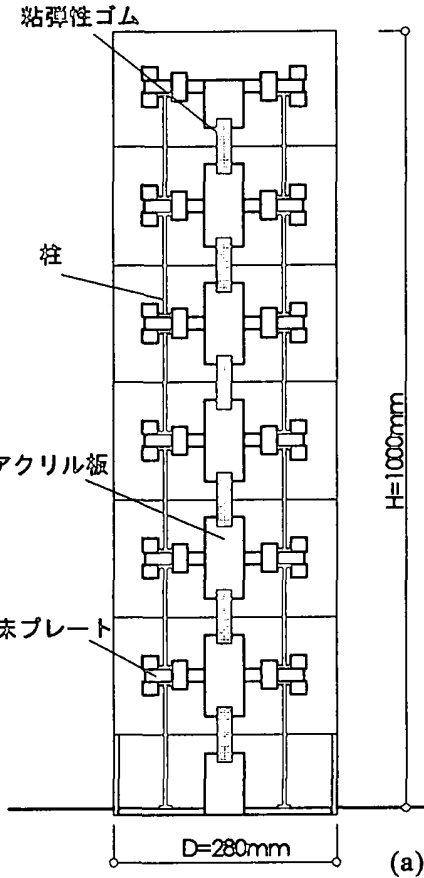

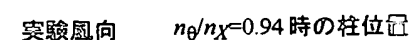

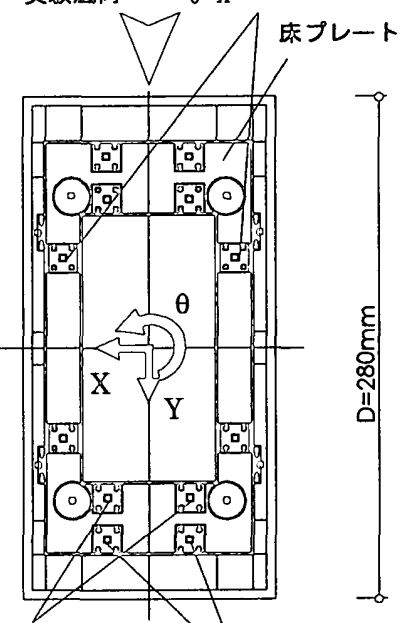
$n_{\theta} / n_{X}=1.11$ 時の柱位置

$n_{\theta} / n_{X}=1.32$ 時の柱位式 $B=140 \mathrm{~mm}$

(b) 平面图

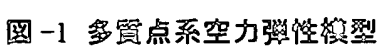

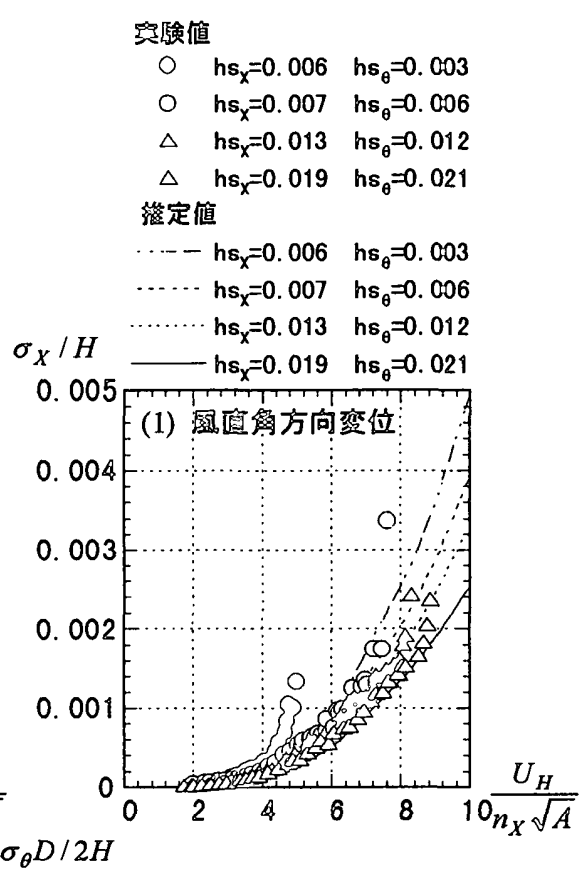

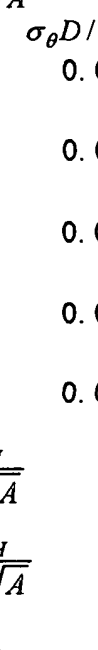

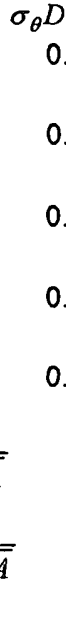

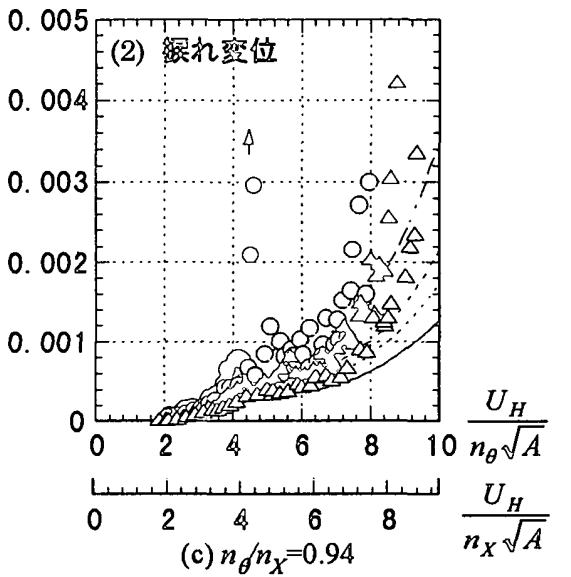


の標準偏差の変化を示す. 図中の曲線は, 動的天秤より得られた転 倒モーメントおよび㨭りモーメントを用いてスペクトルモーダル解 析により求めた応答推定值である. 図 -2 の $n_{\theta} / n_{X}=1.32$ と 0.96 の結 果は文献3)に掲載されているものと同様である.なお, $h s_{X}$ が $0.8 \%$ 以下の風直角方向変位において実験值が途中で途切れているものが あるが，これは㨝れ変位に発散的な増加が生じた為に測定を打ち 切ったことによる.

風直角方向振動では, $n_{\theta} / n_{X}$ が 0.94 の場合, 掭れ振動の増加に伴 う風直角方向振動の急激な增加が見られ, 実験值が推定值より大き くなる.一方, $n_{\theta} / n_{X}$ が 1.32 の場合, 実験風速の範囲では急激な応 答変位の増加は示さず, 実験值は推定值と同程度か小さい. $n_{\theta} / n_{X}$ が 1.11 では，風直角方向振動には 0.94 の場合のような急激な态答 変位の増加は見られないが, 構造減衰定数 $h s_{X}$ が $1 \%$ より小さい場 合, $U_{H} / n_{X} \sqrt{A}=6$ 付近から実験值は推定值を上回る傾向を示す.

㨭れ振動は構造減衰定数 $h s_{\theta} \not ゙ 0.5 \sim 0.6 \%$ の場合を除き固有振動 数比によらずほぼ同様の応答性状を示す. $h s か ゙ ~ 0.3 \%$ 程度の非常に 小さな場合, 㧖れ応答変位は $U_{H} / n_{\theta} \sqrt{A}=4$ 付近から急激に增加寸 る. $h s_{\theta}$ が $1 \%$ 程度より大きい場合, $U_{H} / n_{\theta} \sqrt{A}=8$ 付近までは実験
值と推定值はほぼ同様の值を示すが,この無次元風速以上では実験 值が推定值を上回る. $h s_{\theta}$ が $0.5 \sim 0.6 \%$ では固有振動数比によって 㨭れの応答性状は異なり, $n_{\theta} / n_{X}$ が0.94の場合 $U_{H} / n_{\theta} \sqrt{A}=8$ 付近ま で実験值が推定值とほぼ同様の值を示寸のに対し, $n_{\theta} / n_{X} か ゙ 1.11$ の 場合, $U_{H} / n_{\theta} \sqrt{A}=5$ 付近から発散的な増加を示す. また, $n_{\theta} / n_{X}$ が 1.32 の場合これらの中間的な応答性状となっている.

\section{2 応答加速度のパワースペクトル密度および自己相関関数}

図-3に忘答変位のパワースペクトル密度に $\omega^{4}$ を挂けて得られる 応答加速度の無次元パワースペクトル密度を示す.なお, 図中の矢 印はパワースペクトル密度のピーク周波数を示し, 実線および点線 は後述する自己相関関数の近似結果から求めたパワースペクトル值 を示す. 応答加速度のパワースペクトル密度には, 風直角方向およ び据れの固有振動数以外の周期的な振動成分は見られない.

㨭れ忘答加速度のパワースペクトル密度の実験值には無次元風速 および固有振動数比に関わらず㧖れの固有振動数のみにピークが見 られる. 風直角方向応答加速度のパワースペクトル密度は, 無次元 風速3付近では風直角方向の固有振動数におけるピークのみ明瞭で

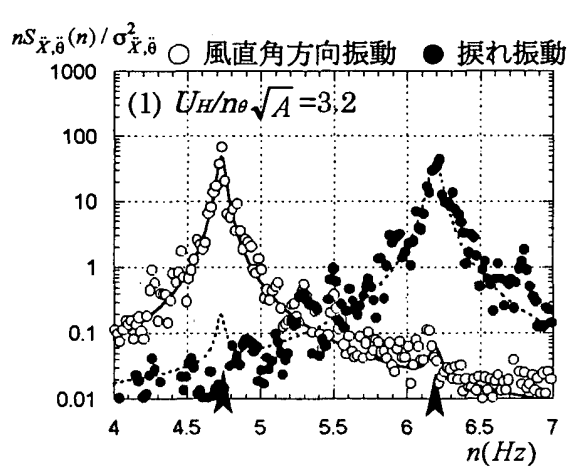

$n S_{\ddot{X}, \ddot{\theta}}(n) / \sigma_{\ddot{X}, \ddot{\theta}}^{2} \bigcirc$ 風直角方向振動

据れ振動

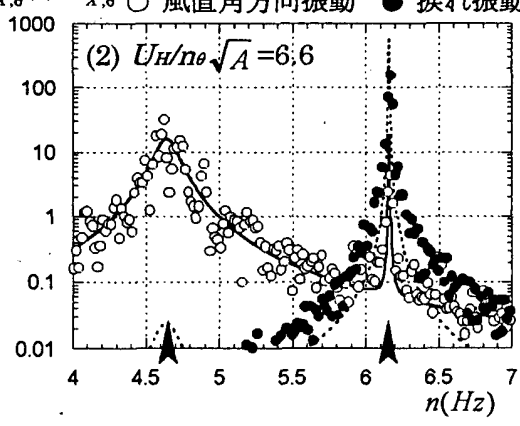

(a) $n_{\theta} / n_{X}=1.32, h s_{X}=0.8 \%, h s_{\theta}=0.5 \%$
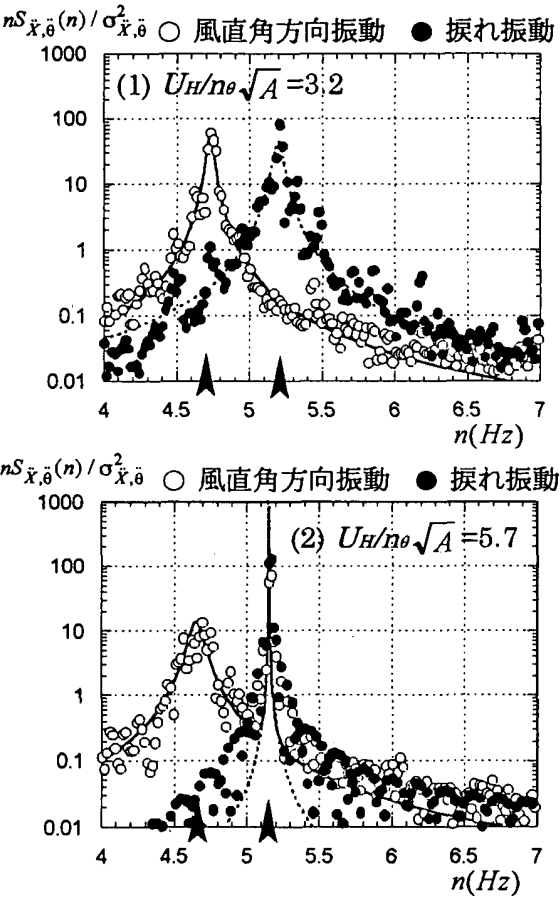

(b) $n_{\theta} n_{X}=1.11, h s_{X}=0.7 \%, h s_{\theta}=0.6 \%$

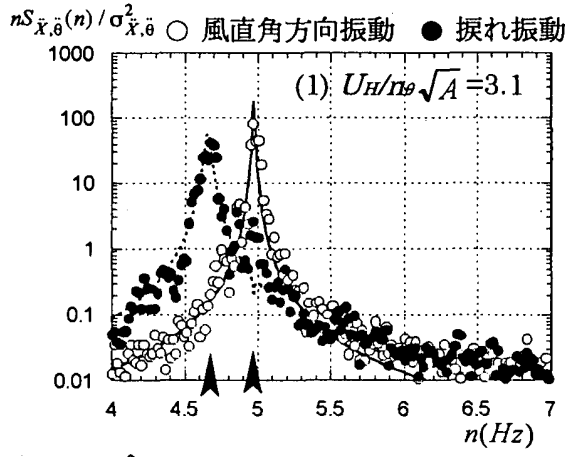

$n S_{\ddot{X}, \ddot{\theta}}(n) / \sigma_{\ddot{X}, \ddot{\theta}}^{2} \bigcirc$ 風值角方向振動 ○据れ振動

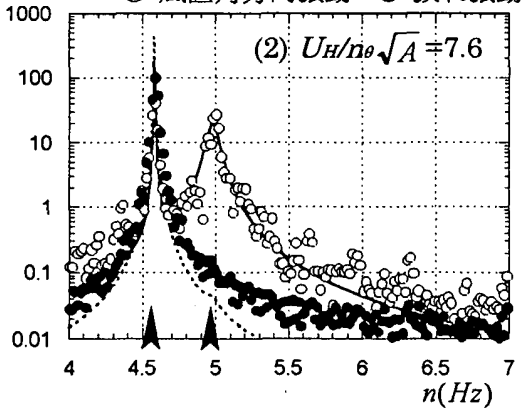

(c) $n_{\theta} / n_{X}=0.94, h s_{X}=0.7 \%, h s_{\theta}=0.6 \%$

図 -3 応答加速度のパワースペクトル密度 (図中の実線および点線は(1.1) 式および(1.2) 式による近似值を示す)

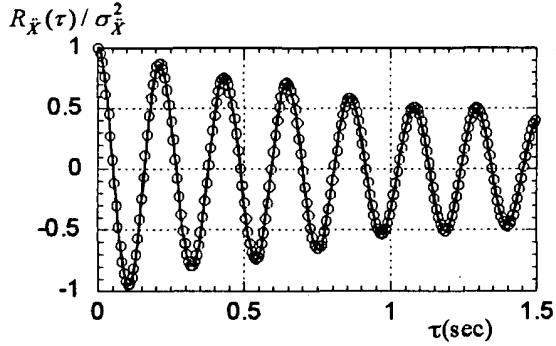

(a) $n_{\theta} / n_{X}=1.32, U_{H} / n_{\theta} \sqrt{A}=6.6$

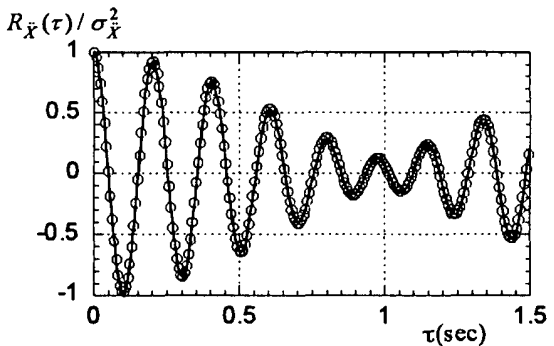

(b) $n_{\theta} / n_{X}=1.11, U_{H} / n_{\theta} \sqrt{A}=5.7$

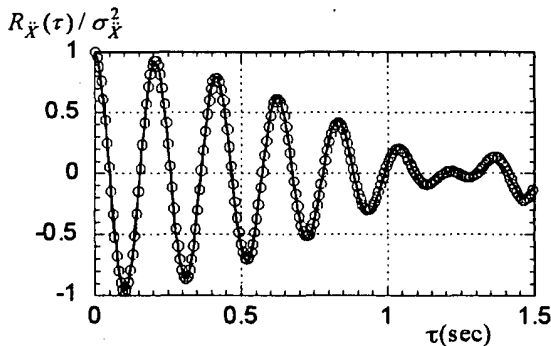

(c) $n_{\theta}\left(n_{X}=0.94, U_{H} / n_{\theta} \sqrt{A}=7.6\right.$

$h s_{X}=0.8 \%, h s_{\theta}=0.5 \%$

$h s_{X}=0.7 \%, h s_{\theta}=0.6 \%$

$h s_{X}=0.7 \%, h s_{\theta}=0.6 \%$

図 -4 風直角方向応答加速度の自己相関関数（図中の実線は(1.1) 式および(1.2) 式による近似值を示す) 
ある.しかし，㨭れの応答変位が大きな值を示寸無次元風速におけ る風值角方向応答加速度のパワースペクトル密度は,いずれの固有 振動数比の場合も風直角方向の固有振動数における比較的緩やかな

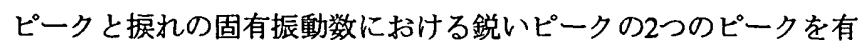
する. $n_{\theta} / n_{X}$ が 0.94 および 1.11 の風直角方向応答加速度のパワース ペクトル密度のピーク值は, 㨝れの固有振動数成分が風直角方向の 固有振動成分より大きな值を示す. 同様の結果は, 河井7による勾 配流中での振動実験からも示されている.

図 Aに風直角方向の応答加速度の自己相関関数を示す. 応答加 速度波形は，変位のフーリエスペクトルに $(i \omega)^{2}$ を掛けてフーリエ 逆変換することによって求めた. その際，2次モード以上の高次成 分を除去するため $10 \mathrm{~Hz}$ 以上の振動数成分は $1 / 1000$ 倍した. $n_{\theta} / n_{X} か ゙$ 0.94 および1.11の場合, 風直角方向加速度の自己相関関数はビート した波形となる.これは, パワースペクトル密度からも明らかなよ うに, 風直角方向と㨝れの固有振動数のピークが同程度のパワーを 有する為である. 一方, 固有振動数比 $n_{\theta} / n_{X}$ が 1.32 の場合は, 全体 的には単調な減衰波形であるが, 個々のピークには若干の上下が見 られる。

先に述べたように, 風直角方向および据れの応答加速度のパワー スペクトル密度には, 風直角方向の固有振動数之据れの固有振動数 以外の周期的な振動成分が見られない. そこで, 応答加速度の自己 相関関数が風直角方向と㨭れの固有振動数の自由振動波形の和で表 されると仮定して(1.1)式および(1.2)式で風直角方向応答加速度お よび㨭れ态答加速度の自己相関関数を近似した。

$$
\begin{array}{r}
R_{\ddot{X}}(\tau) / \sigma_{\ddot{X}}^{2}=\kappa_{X X} \exp \left(-2 \pi n^{\prime}{ }_{X} h_{X} \tau\right) \cos \left(2 \pi n^{\prime}{ }_{X} \tau\right) \\
+\kappa_{X \theta} \exp \left(-2 \pi n_{\theta}{ }_{\theta} h_{\theta} \tau\right) \cos \left(2 \pi n^{\prime} \tau\right) \\
R_{\ddot{\theta}}(\tau) / \sigma_{\ddot{\theta}}^{2}=\kappa_{\theta X} \exp \left(-2 \pi n_{X}{ }_{X} h_{X} \tau\right) \cos \left(2 \pi n^{\prime}{ }_{X} \tau\right) \\
+\kappa_{\theta \theta} \exp \left(-2 \pi n^{\prime}{ }_{\theta} h_{\theta} \tau\right) \cos \left(2 \pi n_{\theta} \tau\right)
\end{array}
$$

ここで, $h_{X, \theta}$ : 等価減衰定数 (構造減衰定数 $h s^{+}$空力減衰定数 $h a$ )， $n_{X, \theta}^{\prime}$ : 空力則性が加味された見かけ上の固有振動数， $\kappa_{i j}$ : 自己相関 関数に占める風直角方向および㨭れ振動の固有振動数に対応する成 分 (以下，固有振動数成分と呼ぶ)の割合で最初の添え字はは振動方 向を, 二番目の添え字 $j$ は固有振動数成分を表す. なお, 風直角方
向加速度の自己相関関数の近似((1.1)式)では $\kappa_{X X}, \kappa_{X \theta}, n_{X}^{\prime}$ および $h_{X}$ をパラメーターとし，㨭れ加速度の自己相関関数の近似 ((1.2) 式)では $\kappa_{\theta X}, \kappa_{\theta \theta}, n_{\theta}^{\prime} お よ ひ ゙ h_{\theta}$ をパラメーターとして, 実験值との 二乗誤差が最小となるように各パラメーターを決定した.

図-3および図ー4には(1.1)式および(1.2)式による近似結果を曲 線で示しているが, パワースペクトル密度, 自己相関関数ともよく 一致した結果が得られている.

図-5に風直角方向応答加速度にお付る風直角方向の固有振動数 成分および搌れの固有振動数成分の割合 $\kappa_{X X}, \kappa_{X \theta}$ の固有振動数比 による変化を示す.なお, 㧖れ振動に占める風直角方向の固有振動 数成分 $\kappa_{\mathrm{Q} X}$ は $U_{H} / n_{\theta} \sqrt{A}=10$ 以下では構造減衰定数および固有振 動数比によらず $1 \%$ 以下であった. また, 空力剛性による固有振動 数の変化は本実験の筑囲では $2 \%$ 以下と小さかった.

$n_{\theta} / n_{X}$ が 1.32 の場合, 風直角方向振動における $\kappa_{X \theta}$ は $\kappa_{X X}$ に比べ 小さい. 一方, $n_{\theta} / n_{X} か ゙ 0.94$ の場合, 全ての構造減衰定数において $\kappa_{X \theta}$ が風速の増加に伴い増加し, $\kappa_{X \theta}$ と $\kappa_{X X}$ がほぼ同程度の值を示 す. $n_{\theta} / n_{X}$ が 1.11 の場合は，㨝れの応答変位に発散的な増加の見ら

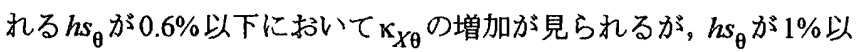
上の場合には $\kappa_{X \theta}$ の割合は小さい. したがって, 固有振動数が接近 した時に生じる風直角方向振動の急激な応答変位の増加は, 主とし て風直角方向振動における据れの固有振動数成分 $\kappa_{X \theta}$ の増加による ものである.

4. 摖渠

本項では自己相関関数の近似結果を基に，まず, 建築物の風応答 性状に大きく影響する空力減衰定数の固有振動数比による変化に関 して検討する. 続いて, 風直角方向応答変位の急激な増加の主な要 因である据れの固有振動数成分 $\kappa_{X \theta}$ に関して考察する.

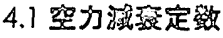

図-6に自己相関関数の近似結果から得られた等価減衰定数 $(h s+h a)$ から無風時の自由振動実験より求めた檴造减衰定数 $h s$ を差 し引いて求めた空力减衰定数 $h a$ を示寸. 図-6には大熊他 ${ }^{8}$ による 3次元模型を用いた強制加振実験の結果から求めた空力減衰定数ha も示した. なお，文献 8)の強加振実験は，本研究と同様のアスペ クト比および辺長比を有する模型を用いて $\alpha=1 / 4$ の勾配流中で $2 \mathrm{H}$

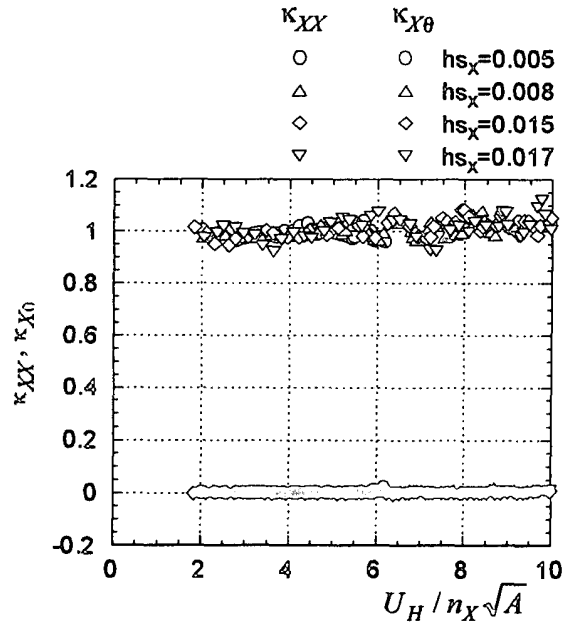

(a) $n_{\theta} n_{X}=1.32$

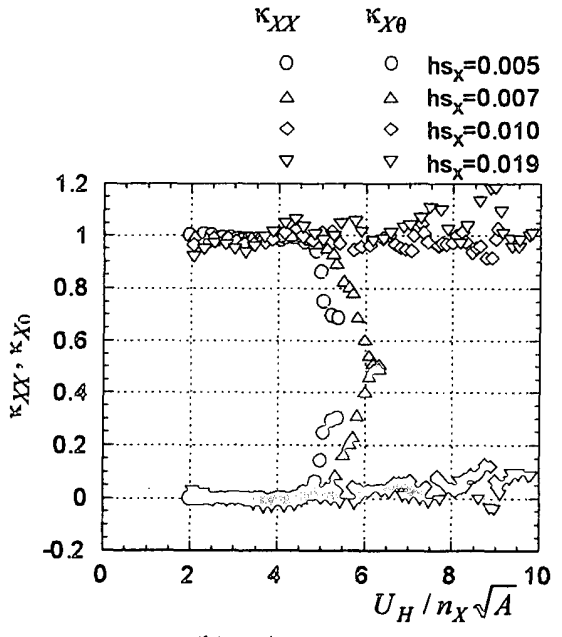

(b) $n_{\theta} n_{X}=1.11$

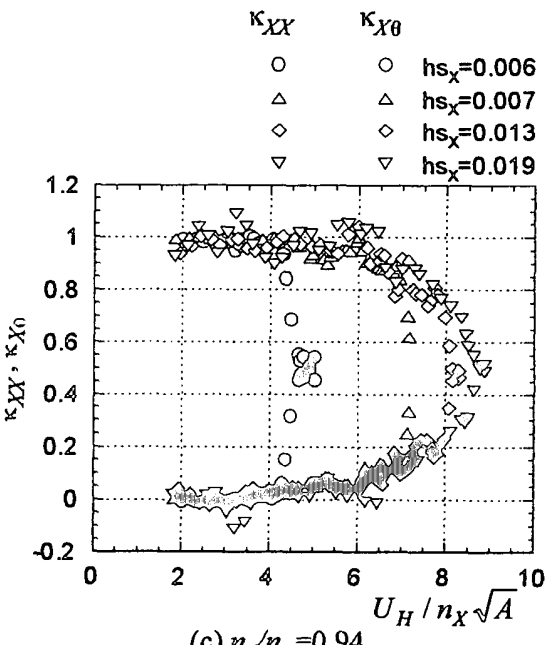

(c) $n_{\theta} / n_{X}=0.94$

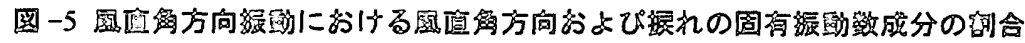


3 および $2 \mathrm{H} / 5$ 高さの振動依存層風力が測定されている.ここでは, $2 \mathrm{H} / 3$ 高さでの振動依存層風力が高さ方向に一様に作用すると仮定し て (2.1) 式および(2.2) 式によって空力堿衰定数 $h a$ を求めた.

$$
\begin{aligned}
& h a_{X}=-\frac{C_{L i}}{x_{0} / H} \frac{3}{16 \pi^{2}} \frac{\rho_{a}}{\rho_{b}}\left(\frac{U_{H}}{n_{X} \sqrt{B D}}\right)^{2} \frac{D}{2 H} \\
& h a_{\theta}=-\frac{C_{M i}}{\theta_{0}} \frac{3}{16 \pi^{2}} \frac{\rho_{a}}{\rho_{b}}\left(\frac{U_{H}}{n_{\theta} \sqrt{B D}}\right)^{2} \frac{D^{2}}{2 j^{2}}
\end{aligned}
$$

ここで, $C_{L i}, \dot{C}_{M i}$ : 強制加振実験より得られた $2 \mathrm{H} / 3$ 高さにおける 振動依存層揚力係数および振動依存層据りモーメント係数, $x_{0}, \theta_{0}$ : 模型頂部での変位片振幅, $H, B, D$ : それぞれ模型の高さ, 見附幅お よび奥行き, $j=\sqrt{I / m}$ (回転半径, $I:$ 慣性モーメント, $m:$ 質量), $\rho_{b}$ : 建物密度 $\left(=M / 3 B D H, M\right.$ : 風直角方向振動の一般化質量), $\rho_{a}$ : 空気密度である.

風直角方向，㨝れとも $h s$ が $1 \%$ を超える場合，空力减衰定数 $h a$ はばらつくが, hs が 1\%末満の結果と一致した傾向を示している.

風直角方向振動の空力堿衰定数 $h a_{X}$ は, 無次元風速 4 付近で $-0.4 \%$ 程度の極小值を示し，風速とともに単調に増加する．据り振動の $h a_{\theta}$ は, 無次元風速 3 付近で $+0.5 \%$ 程度の極大值を示し, 無次元風 速4付近から負減衰となる. 据れの応答变位に発散的な増加が見ら れる $h s_{\theta}<0.5 \%$ の場合, $h a_{\theta}$ は $h s_{\theta}$ とほぼ同様の值まで減少し, 等価 減衰定数 $\left(h s_{\theta}+h a_{\theta}\right)$ はほぼ0になる. $h s_{\theta}>0.5 \%$ では, $h a_{\theta}$ はさらに減 少し, 無次元風速 5〜8では - $0.5 \%$ 程度の一定值を示し, 無次元風 速 8 を超える風速付近から再び減少する.

風直角方向振動の空力减衰定数 $h a_{X}$ は, 固有振動数比 $n_{\theta} / n_{X} \not ゚$ 0.94 の無次元風速6以上の時に他の固有振動数比と比べ多少差が見
られる他は, 固有振動数比による大きな差違は見られない. $n_{\theta} / n_{X}$ が 0.94 の場合, 他の固有振動数比の場合と比べ無次元風速6以上で は $h a_{X}$ が小さ目の值を示すが, $h a_{X}$ は負值にはならない. 㧖れ振動 の $h a_{\theta}$ にも固有振動数比による大きな差は見られないが, 無次元風 速 5〜8 の時の值が固有振動数比によって若干異なっている. この. ため図-2における据れ変位の固有振動数比による応答性状の差が $h s_{\theta}=0.5 \sim 0.6 \%$ の時に生じているものと思われる.

応答加速度波形から求めた空力減衰定数と強制振動実験結果よ り求めた空力減衰定数を比較すると,值そのものは異なるが両者は よく一致した傾向を示している.したがうて, 固有振動数の接近が 風直角方向および据れ方向の空力减衰定数に与える影響は小さい.

\section{2 㨝れ振動に伴う風直角方向振動依存風力}

応答加速度の自己相関関数の近似パラメーターのうち, 風直角方 向振動における㨭れの固有振動数成分の割合 $\kappa_{X \theta}$ が㧖れ振動に伴う

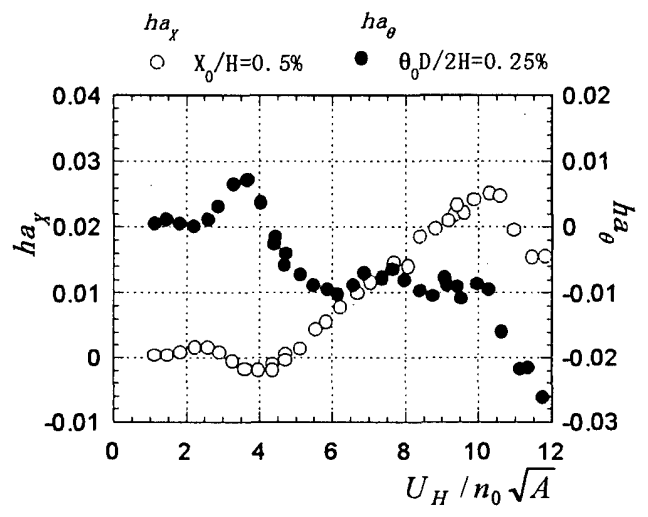

(c) 文献 8)の強制加振実験結果より求めた空力減衰定数
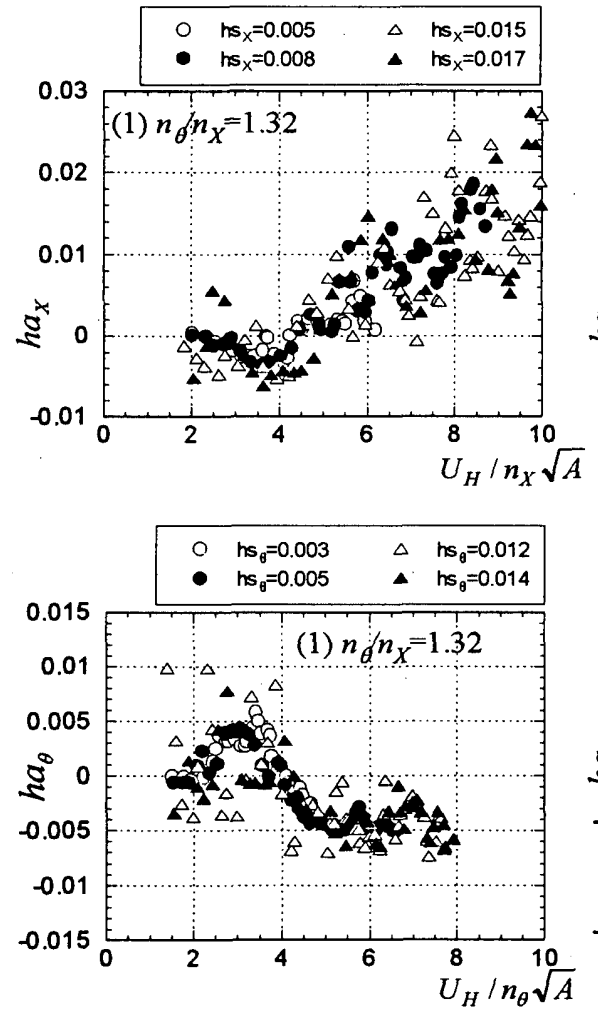

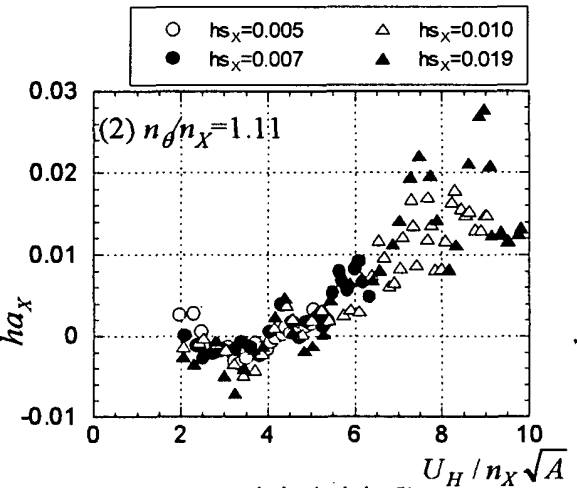

(a) 風直角方向振勳

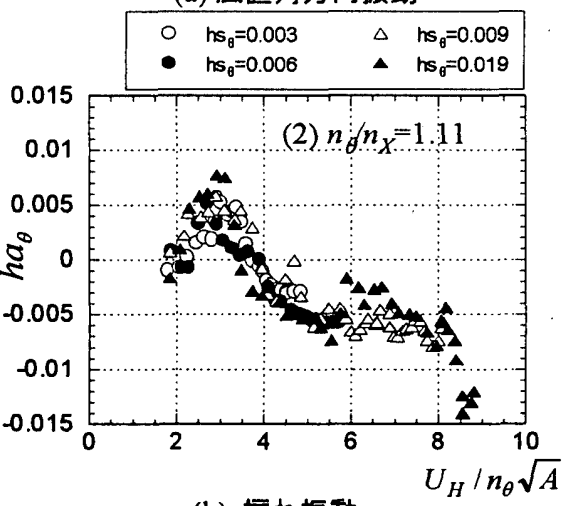

(b) 挨れ振動
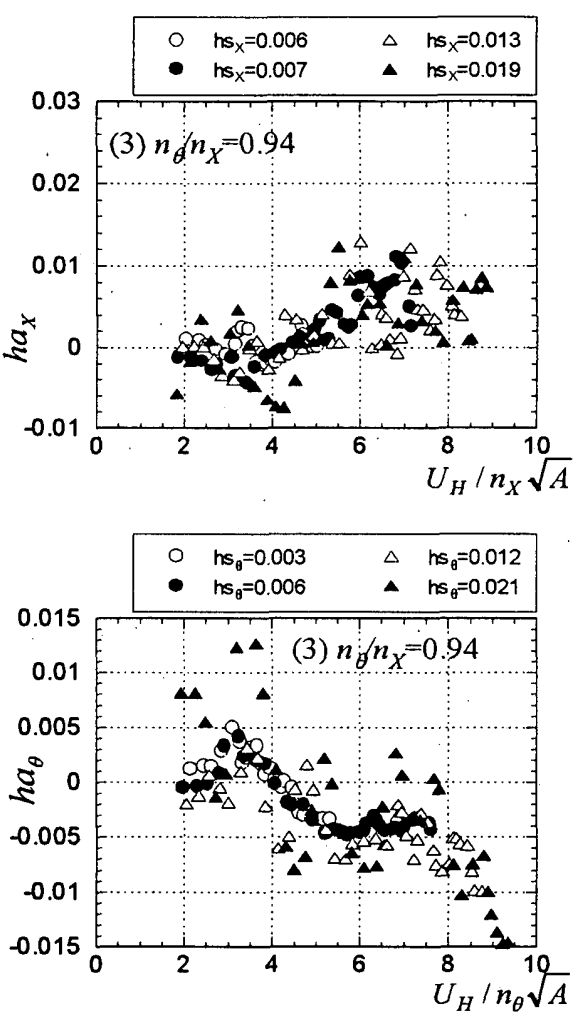

図 -6 空力隇衰定数 
風直角方向の振動依存風力,すなわち振動依存風力の連成項による ものであり，かつ，据れ振動に伴う風直角方向の振動依存風力によ る応答が外力によるものと同様にランダム振動における強制振動解 として扱えると仮定して,振れ振動に伴う風直角方向の振動依存風 力係数を(3.1)式および(3.2)式により求めた.

$$
\begin{aligned}
& \frac{C_{L \theta}^{\prime}}{\sigma_{\theta \theta}}\left(\frac{U_{H}}{n_{\theta}^{\prime} \sqrt{A}}\right)^{2}=\frac{\sigma_{L \theta}}{\sigma_{\theta \theta} q_{H} D H}\left(\frac{U_{H}}{n_{\theta}^{\prime} \sqrt{A}}\right)^{2} \\
& =\frac{\sigma_{\ddot{X}} \sqrt{\left|\kappa_{X \theta}\right|}}{D \sigma_{\ddot{\theta}} \sqrt{\left|\kappa_{\theta \theta}\right|}} \frac{8 \pi^{2}}{3} \frac{\rho_{b}}{\rho_{a}}\left(\frac{n_{X}^{\prime}}{n_{\theta}^{\prime}}\right)^{2} \frac{1}{\sqrt{\chi\left(n_{\theta}^{\prime} / n_{X}^{\prime}\right)}} \\
& \chi\left(n_{\theta}{ }_{\theta} / n^{\prime}{ }_{X}\right)=\frac{1}{\left\{1-\left(n_{\theta}^{\prime} / n^{\prime}{ }_{X}\right)^{2}\right\}^{2}+4 h_{X}^{2}\left(n_{\theta}{ }_{\theta} / n^{\prime}{ }_{X}\right)^{2}}
\end{aligned}
$$

ここで, $\sigma_{L \theta}$ : 㨭れ振動に伴う風直角方向振動依存風力の標準偏差, $h_{X}$ : 風直角方向の等価減衰定数, $q_{H}$ : 模型高さの速度圧である.

また, 先の仮定より，㨝れ振動に伴う風直角方向の振動依存風力 と据れ振動の位相差 $\varphi_{L \theta}$ は, 風直角方向応答加速度と㨭れ忍答加速 度の相互相関関数より(4.1)式および(4.2)式によって求められる.

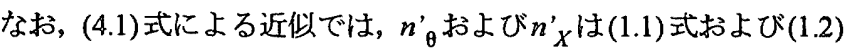
式による自己相関関数の近似結果から得られた值を用いた。

$$
\begin{aligned}
R_{\ddot{X} \ddot{\theta}}(\tau)= & \overline{\ddot{X}(t+\tau) \ddot{\theta}(t)} \\
= & A_{\theta} \exp \left(-2 \pi n^{\prime}{ }_{\theta} h_{\theta} \tau\right) \cos \left(2 \pi n^{\prime} \tau+\varphi_{\theta}\right) \\
& +A_{X} \exp \left(-2 \pi n^{\prime}{ }_{X} h_{X} \tau\right) \cos \left(2 \pi n_{X}^{\prime} \tau+\varphi_{X}\right) \\
\varphi_{L \theta}= & \varphi_{\theta}+\tan ^{-1} \frac{2 h_{X} n_{\theta}^{\prime}{ }_{\theta} / n_{X}^{\prime}}{1-\left(n^{\prime}{ }_{\theta} / n^{\prime}{ }_{X}\right)^{2}}
\end{aligned}
$$

ここで, $A_{\theta}, A_{X}$ : 初期振幅, $\varphi_{\theta}, \varphi_{X}$ : 位相差である.

図 -7 に風直角方向応答加速度と搌九応答加速度の相互相関関数 および近似結果の一例を示す.相互相関関数の近似結果は自己相関 関数と同様によい近似が得られた.

図-8に据れ振動に伴う風直角方向振動依存風力係数および位相 差の推定結果を示す.なお, 振動依存風力係数および位相差の推定 には(3.2)式および(4.2)式で用いた応答関数が㨭れの固有振動数に おける值を用いている事を考虑し, 㨝れ振動の等価減衰定数 $\left(h s_{\theta}+h a_{\theta}\right)$ が $1 \%$ 末满のものを用いた. 振動依存風力係数は, 無次元 風速の二乗を掛けたものを表示している. 図-8には大熊他 ${ }^{8)}$ の強 制加振実験における $2 \mathrm{H} / 3$ 高さでの測定結果も併記した.

据れ振動に伴亏風直角方向の振動依存風力係数は固有振動数比に よらずほぼ同様の值を示す. 位相差は, $n_{\theta} / n_{X} か ゚ 1.32$ の時, 無次元 風速4付近において他の固有振動数比の場合と比べ多少差があるが ほぼ同様の傾向を示している. 無次元風速4付近における固有振動 数比による差は, $n_{\theta} / n_{X}$ が 0.94 および1.11 の時に風直角方向振動に 伴って生じる振動依存据りモーメントを考虑していないためと思わ れる．振動依存風力係数は，無次元風速4付近で極小值を示し，無 次元風速 4 以上の風速では, 風速のほぼ 3 乗に比例して増加する. 位相差は, 無次元風速 4 付近で- $\pi$ 付近から+ $/ 2$ まで急激に変化し， 無次元風速 5 以上の風速では緩やかな変化を示す.

応答加速度から求めた振動依存風力と強制加振実験結果を比較す

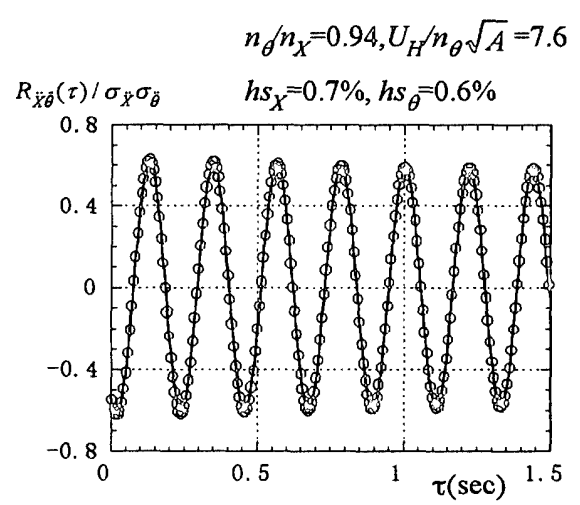

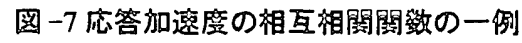

（图吅の穾線は(4.1) 式による近似給黑)

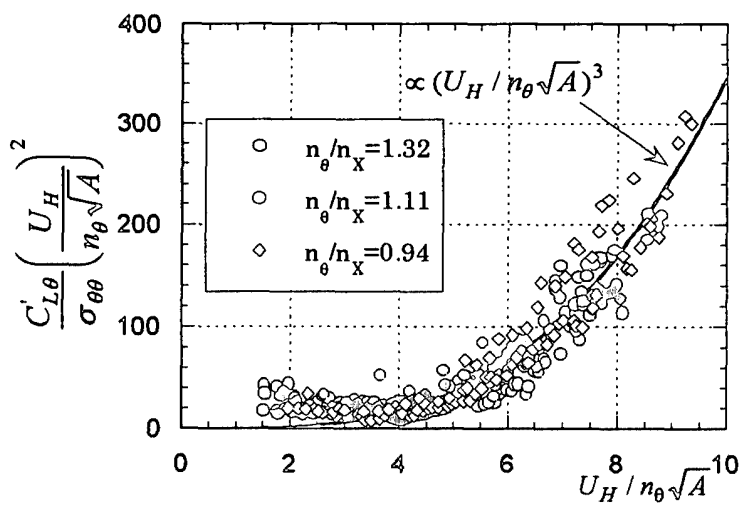

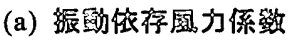

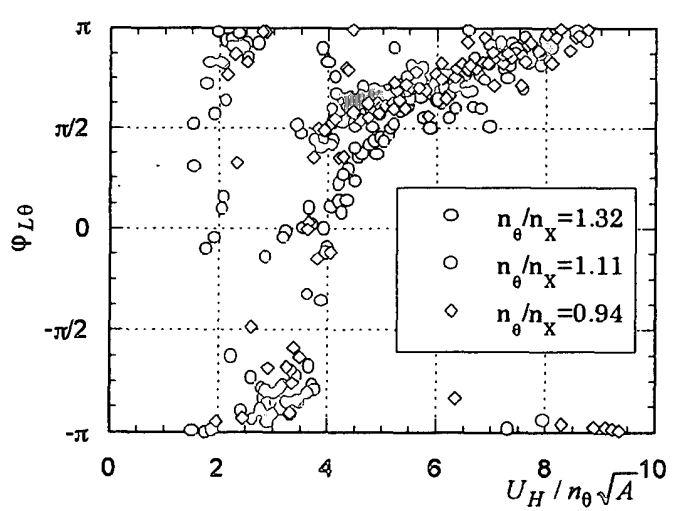

(b) 位祖䇺

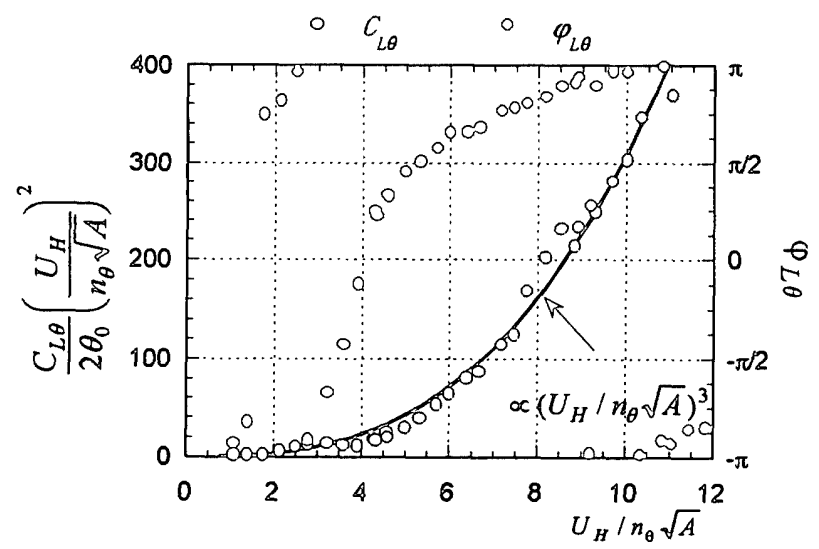

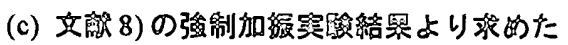
哏到儌存图力 $\left(\theta_{0} D / 2 H=0.25 \%\right)$

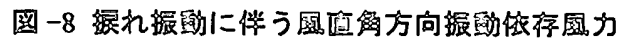


ると，振動依存風力係数および位相差とも同様の傾向を示してお り, 先の仮定の妥当性が示された. また，空力減哀定数と同様に， 固有振動数比が㧖れ振動に伴う風直角方向の振動依存風力に与える 影響は小さい. したがって, 固有振動数比による風直角方向の風応 答性状の差は(3.2)式で示される風直角方向の応答倍率の固有振動 数比による差によって生じる. また, これらの結果から, 振動依存 風力の連成項が支配的となる風店答の振動形は, 風直角方向と据れ 振動が(4.2)式から得られる位相差 $\varphi_{\theta}$ を有する事が分かる.すなわ ち，風上側もしくは風下側のどちらを大きく振る振動形となるか は, 振動依存風力の位相差と応答倍率の位相差によって決定され る.

\section{5. 結論}

辺長比 2 の高層建築物では, 風直角方向と㧖れの固有振動数が接 近した場合に風直角方向の応答変位に急激な増加が生じる.これ は, 風直角方向振動における㧖れの固有振動数成分の増加によるも のであり，㨭れ振動に伴って生じる風直角方向の振動依存風力，い わゆる振動依存風力の連成項に起因する. しかし, 風直角方向と㨭 れの固有振動数比 $n_{\theta} / n_{X}$ が空力減衰定数あるいは据れ振動に伴う風 直角方向の振動依存風力係数および位相差に与える影響は小さく, $n_{\theta} / n_{X}$ による風直角方向の風応答性状の差違は, 据れの固有振動数 における応答倍率の差によって生じる. また, 振動依存風力の連成 項による応答は, 風直角方向と㧖れの固有振動数に数\%の差を有 する場合には,外力による風态答と同様に強制振動として扱うこと が可能である.

\section{参考文献}

1) 例えば，大能武司，丸川比佐夫，鶴見俊雄，山本学 : 高層建筑 物の空力不安定振動の予測, 日本建築学会大会学術講演梗概集(関 東) 1993 年 9 月, pp1127-1128

2) 例えば, Isyumov,N., The Aeroelastic Modeling of Tall Buildings, International Workshop on Wind Tunnel Modeling for Civil Engineering Applications, Cambridge Univercity Press 1983, pp373-407

3) 丸川比佐夫, 片桐純治, 睠村章, 藤井邦雄 : 多質点系弾性模型 の開発と高層建築物の風応答評価についての検討，日本建築学会 構造系論文集第 484 号, pp39-48

4) 片桐純治, 丸川比佐夫, 勝村章, 藤井邦雄 : 偏心を有する高層 建築物の風応答に関する実験的研究, 第 14 回風工学シンポジウム (1996), pp443-448

5) 大熊武司, 木村充幸, 伊藤純子, 宮澤浩史 : 矩形断面構造物の 曲け㨝れ空力不安定振動に関する研究, 日本建築学会大会学術講 演梗概集(近畿), 1996年9月, pp245-246

6) 吉村直樹, 丸川比佐夫, 大能武司, 高橋尚二: 高層建築物の風 による並進・据れ振動実験, 日本建築学会大会学術講演梗概集(東 海)1994 年 9 月, pp223-224

7) 河井宏允 : 高層建築物の渦励振, ギャロッピング, フラッター, 第 12 回風工学シンポジウム(1992), pp267-272

8) 大熊武司, 片桐純治, 丸川比佐夫, 宮澤浩史, 片岡里美 : 高層 建築物に作用する振動依存風力特性に関する実験的研究, 日本建 築学会大会学術講演梗概集(関東)1997 年 9 月, pp187-190 